\title{
Effects on Welfare Brought by Changes in Taxation - Focusing on Low-income Population in America
}

\author{
Zheng Yang \\ Bullis Sschool \\ 2400 Stratton Drive, Potomac, Maryland, 20854
}

\begin{abstract}
Taxations policies have been a controversial topic debated by the government of the US for many years. This article will focus on Obamacare, using analysis of variance, to study trends in the college enrollement rates, employment rates, and marriage stability in the US. Trends in averages demonstrate that college enrollments, employment rates, and marriage stability all increase after the legislation of Obamacare; however, the result of variance analysis proves that changes in these three areas (college enrollments, employment rates, marriage) are not significant. This shows that Obamacare did not significantly improve welfare of the low-income population in the US.
\end{abstract}

Keywords-Taxations; Low-income population; effects of welfare; variance analysis

\section{INTRODUCTION}

Altering taxation was not only a slogan in President Trump's presidential campaign advertising, in that his administrative method demonstrates to be implementing those campaign ad promises. As one of the most developed countries in the world, the U.S. citizens are not still receiving free medical services; instead, the constantly increasing cost of medical services is dragging down the ones who are below the poverty threshold. During the presidency of Obama a series of amendments in the U.S. healthcare system were proposed (Affordable Care Act or simply Obamacare), hoping to decrease the burden of medical expenses on low-income families. However, the policies taken by Trump annulled most of Obama's effort, raising a question that how Obamacare did really benefit the low-income population. Answering this question not only can help us gain more understating about quality of life of different social classes, but also more clarifies Trump's policies. In addition, the author is volunteering to help low-income families file their tax returns. This article tries to utilize data before and after Obama's amendments in taxation to examine how much they could improve quality of life of the low-income population.

\section{ASSUMPTION}

After proposal of those amendments to the healthcare system, they were being discussed among people and studied by elites. Harrington (2010) reviewed and summarized different opinions [1]. Miller (2012) analyzed its impact on kids' healthcare in Manchester and New Hampshire [2].
Courtemanche and Zapata (2014) analyzed the outcome of those amendments [3]. These researches, explicitly and implicitly, analyzed and discussed the consequences of Affordable Care Act (or Obamacare). Here is discussed the influence of Obamacare from three aspects as follows.

\section{A. Altering Taxation and employment rate of low-income population}

Obama's tax plan included the low-income families; thereby their expenses on medical services cut. This leads to our first hypothesis:

H1: Obama's Affordable Care Act was able to increase the employment rate in below-the- poverty line population.

\section{B. Altering taxation and education of low-income families}

Obama's tax plan not only did diminish the burden on lowincome population caused by medical expenses, but also increased their income, allowing them to increase their expenditures on their offspring's education. Therefore, the second hypothesis is proposed [4-8]:

$\mathrm{H} 2$ : Obama's tax plan was able to increase the number of college enrolments in low-income families.

\section{Altering taxation and stability of families}

Obama's tax plan increased employment rate among lowincome population. This could help these families become more stable. The third hypothesis is therefore:

H3: Obama's new tax plan could make low-income families more stable.

\section{EMPIRICAL ANALYSIS}

Data used in this article is mainly extracted from the Bureau of Census. It encompasses employment rate, enrollment in college, and the number of married couples among low-income population from 2005 to 2015 [9-16].

\section{A. The statistical analysis of college enrollment rate}

The variation tendency of college enrollment rate is depicted in figures 1 , and the statistics of college enrollment rate is depicted in table 1. 


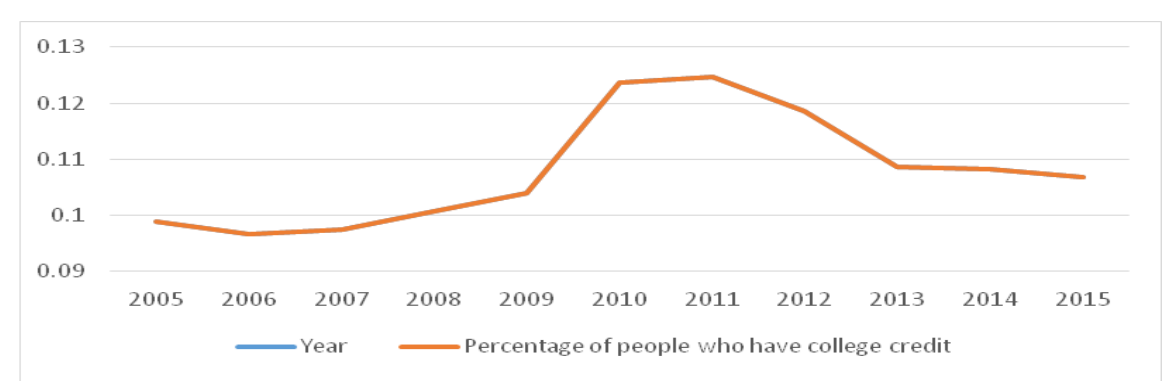

Fig. 1. Percentage of low-income people who earned college degree or above

TABLE I. STATISTICS OF COLLEGE ENROLLMENT RATE

\begin{tabular}{cccc}
\hline Period & $\begin{array}{c}\text { Average college enrollment } \\
\text { rate }\end{array}$ & SD & Coefficient of variation \\
\hline 2010 to 2015 & 0.113 & 0.008 & 0.069 \\
2005 to 2010 & 0.104 & 0.010 & 0.098 \\
2005 to 2015 & 0.108 & 0.010 & 0.094 \\
\hline
\end{tabular}

From the figure 1 and table 1 we know that, from 2005 to 2015 , the percentage of employment slightly decreased; from $23.87 \%$ in 2005 to $23.45 \%$ in 2015 . This ten-year period can be divided into two five-year periods, namely first, from 2005 to 2010, and second, from 2010 to 2015. From 2005 to 2010, the percentage had multiple fluctuations and eventually reached its pick in 2010. However, after 2010, the trend was different. After experiencing a pick in 2010, the percentage slightly decreased, showing that low-income people faced a difficulty finding jobs. In the end, the percentage dropped below $23.5 \%$, a nadir in 2014, which is lower than the initial value in 2005 . However, the average employment rate of the second period (2010 - 2015) increased compared with that of the first period (2005-2010). The average of the whole period (2005-2015) is
$24.48 \%$. From 2005 to 2010 , the average of the percentage of employment is $24.25 \%$, which goes up to $24.78 \%$. For the whole period, the standard deviation is 0.008469 . The standard deviation for the first period is 0.00827259 and slightly higher, 0.00862398 , for the second period. About the correlation coefficient, the first period (2005-2010) carries the value of 0.034119 , and the second period (2010 -2015) carries 0.034803 .

\section{B. The statistical analysis of employment rate among low- income population}

The variation tendency of employment rate among lowincome population is depicted in figures 2 , and the statistics of employment rate among low-income population is depicted in table 2 .

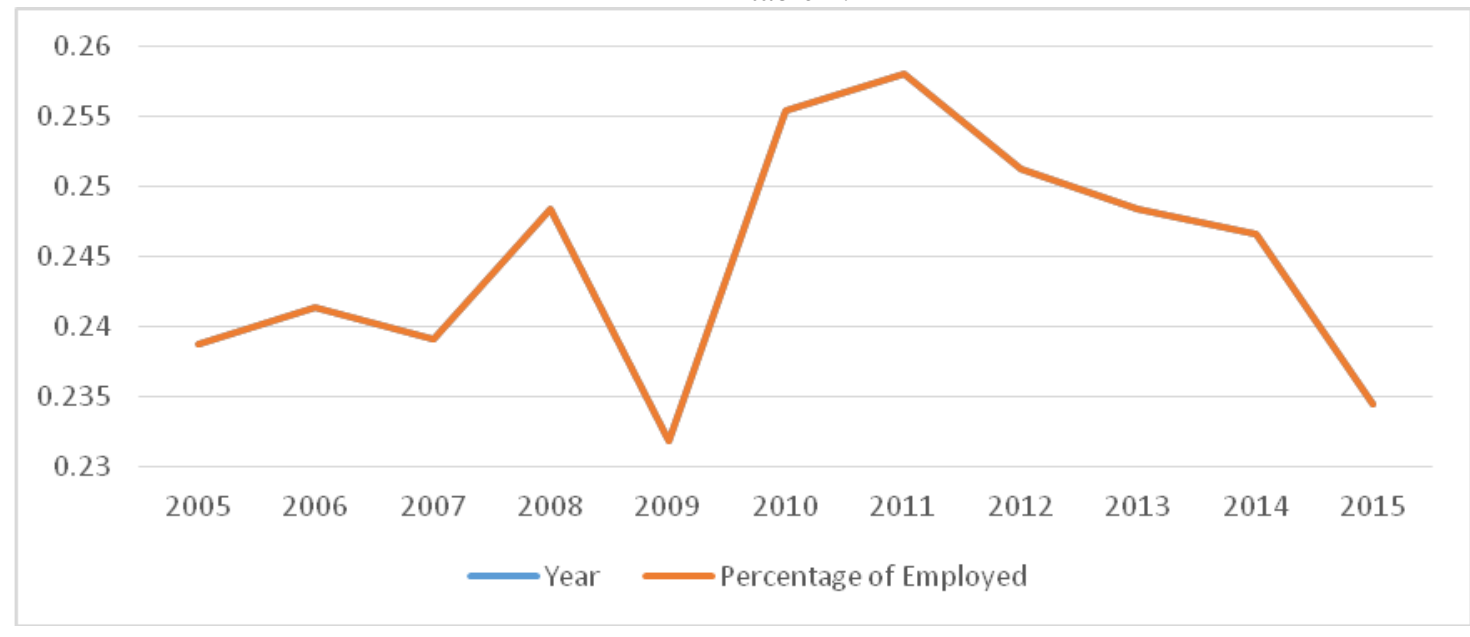

Fig. 2. Employment Rate among Low-income Population 
TABLE II. Statistics OF EMPLOYMENT RATE AMONG Low-INCOME POPULATION

\begin{tabular}{cccc}
\hline Period & Average & Standard Deviation & Coefficient of variation \\
\hline $2010-2015$ & 0.2478 & 0.0086 & 0.0348 \\
$2005-2010$ & 0.2425 & 0.0083 & 0.0341 \\
$2005-2015$ & 0.2449 & 0.0085 & 0.0346
\end{tabular}

From the figure 2 and table 2 we know that, from 2005 to 2015 , the average of the whole population below the poverty line enrolled in college or university is $10.8 \%$. For the first period, the rate of enrolment in a college or university is monotonically increasing with a slow steady pace. And for the second period decreases constantly till it becomes stable. The average of the second period is $11.34 \%$, which is slightly higher than that of the first period; $10.34 \%$.

By comparing standard deviations; which is $1.01 \%$ for the first period and $0.78 \%$ for the second period; it is obvious that

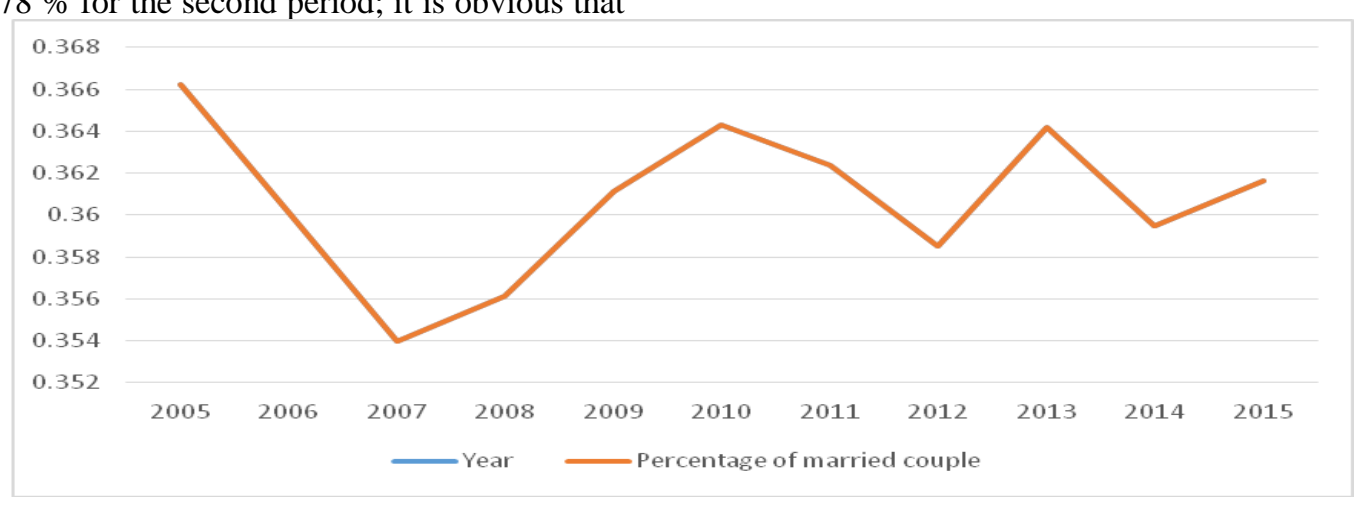

the second period is more stable. Also, the correlation coefficient for the first period is about 0.0692 and for the second period is about 0.0985 .

\section{The statistical analysis of percentage of married households}

The variation tendency of percentage of married households is depicted in figures 3 , and the statistics of percentage of married households is depicted in table 3 .

Fig. 3. Percentage of married households(\%)

TABLE III. Statistics OF PERCENTAGE OF MARRIED HOUSEHOldS

\begin{tabular}{cccc}
\hline Period & Average & Standard Deviation & Coefficient of variation \\
\hline $2005-2010$ & 0.360 & 0.005 & 0.013 \\
$2010-2015$ & 0.361 & 0.002 & 0.006 \\
$2005-2015$ & 0.361 & 0.004 & 0.010 \\
\hline
\end{tabular}

From the figure 3 and table 3 we know that, as figures illustrate, the percentage of married couples among population below the poverty line started to decrease in 2005 and continued to 2007. Afterwards, it started to increase from 2007 to 2010. After 2010, the trend started to fluctuate. For the whole period, the average is 0.36 . During the period of 2010 to 2015, second period, the average is also 0.36, showing a nuance from that of the first period (2005-2010).

The standard deviation for the first period is 0.0046 and for the second period is 0.0022 , showing that the percentage of the first period is less stable.
The correlation coefficient for the first period (2005 to $2010)$ is 0.013 while the correlation coefficient for the second period (2010 to 2015) is 0.00628. Overall, the correlation coefficient is 0.0100 .

\section{Investigation of Obama's tax Plan impact on low-income population}

The variance analysis of Obama's tax Plan impact on lowincome population is depicted in table 4 . 
TABLE IV. INVESTIGATION OF OBAMA'S TAX PLAN IMPACT ON LOW-INCOME POPULATION

\begin{tabular}{c|c|c|c|c}
\hline Variable & $\begin{array}{c}\text { Average } \\
\text { (before reforms) }\end{array}$ & $\begin{array}{c}\text { Averages } \\
\text { (after reforms) }\end{array}$ & $\begin{array}{c}\text { Mean } \\
\text { Difference }\end{array}$ & Probability \\
\hline Employment & 0.2425 & 0.2478 & 0.0053 & 0.323 \\
College Enrollment & 0.1036 & 0.1134 & 0.0098 & 0.112 \\
Number of Married & 0.3603 & 0.3612 & 0.0009 & 0.702 \\
Parents & & & \\
\hline
\end{tabular}

From Table 4, the average of those three values (Employment rate, college enrollment, and number of single parents) increases after Obama proposes his plans. More specifically, the employment rate before Obama's reforms was 0.2425 , while the value increased to 0.2478 afterwards; with an increase of 0.0053 . The enrollment rate in colleges was 0.1036 before Obama's reforms, and went up to 0.1134 afterwards; showing a change of 0.0098 ; the percentage of married couples was 0.3603 before reforms, and it increased to 0.3612 ; with an increase of 0.0009 .

In overall, changes in all those three values are positive. Consequently, we can say that Obama's had increased the employment rate, enrollment rate in college, and the percentage of married couples.

\section{CONCLUSION}

This paper examines Obama's reforms on how much they could improve quality of life of the low-income population based on data before and after Obama's tax plan. It also analyzes significance of changes in data. Based on variance analysis, the three variables considered in this paper, employment rate, enrollment in college, and the percentage of married couples, have values greater than 0.1 , demonstrating that they are not significant. Accordingly, we can conclude that Obama's reforms did not significantly change the employment rate, enrollment rate in college, and the number of married couples among low-income populations.

\section{REFERENCES}

[1] Scott E. Harrington, 2010, The Health Insurance Reform Debate, Journal of Risk and Insurance, 77(1): 5-38.

[2] Sarah Miller,2012, The Impact of the Massachusetts Health Care Reform on Health Care Use among Children, American Economic Review, 102(3): 502-507.

[3] Charles J. Courtemanche, Daniela Zapata,2014, Does Universal Coverage Improve Health? The Massachusetts Experience, Journal of Policy Analysis and Management, 36(1):36-69.

[4] Number and Percent of Persons in Poverty, by Definition of Income: $1999 \quad$ (Revised) https://www. census.gov/library/publications/2000/demo/p60-210.html.

[5] Weighted Average Poverty Thresholds for Families of Specified Size https://www.census.gov/data/tables/time-series/demo/incomepoverty/historical-poverty-people.html.
[6] Annual Poverty by Selected Characteristics: 2009 to 2012 https://www.census.gov/data/tables/time-series/demo/incomepoverty/poverty-dynamics-09-12.html.

[7] Median Household Income (1997 - 2015$)$ https://www.census.gov/did/www/saipe/data/interactive/saipe.html?s_ap pName=saipe \&map_yearSelector=2015\&map_geoSelector=sa_eusd $\&$ s_ measures $=$ mhi_snc \&s_county $=\&$ s_state $=\& s \_d i s t r i c t=\& m e n u=$ trends $\&$ s _USStOnly=y\&s_inclStTot=y.

[8] All ages in Poverty (1997 - $\quad$ 2015) https://www.census.gov/did/www/saipe/data/interactive/saipe.html?s_ap pName=saipe \&map_yearSelector=2015\&map_geoSelector=sa_eusd $\&$ s_ measures $=$ aa_snc\&s_county $=\&$ s_state $=\&$ s_district $=\& m e n u=$ trends $\&$ s_ USStOnly $=y \&$ s_inclStTot $=y$.

[9] Poverty Status in the past 12 months by school enrolment by level of school for the population 3 years and over $(2010$ - 2015) https://factfinder.census.gov/faces/tableservices/jsf/pages/productview.x html?pid=ACS_15_5YR_B14006\&prodType=table.

[10] Poverty Status in the past 12 month by school enrollment by level of school for the population 3 years and over universe: Population 3 years and over for whom poverty status is determined (2005 - 2010) https://factfinder.census.gov/faces/tableservices/jsf/pages/productview.x html?pid=ACS_11_1YR_C14006\&prodType=table.

[11] Poverty Status in the past 12 months of individual by sex by $\begin{array}{llll}\text { employment } \quad \text { status } & \text { 2015) }\end{array}$ https://factfinder.census.gov/faces/tableservices/jsf/pages/productview.X html?pid=ACS_15_5YR_B17005\&prodType=table.

[12] Poverty status in the past 12 months of individual by sex by employment status (2007-2009) https://factfinder.census.gov/faces/tableservices/jsf/pages/productview.X html?pid=ACS_08_3YR_B17005\&prodType=table.

[13] Poverty Status in the past 12 months of individual by sex by employment status (2005 - 2006) https://factfinder.census.gov/faces/tableservices/jsf/pages/productview.x html?pid=ACS_06_EST_B17005\&prodType=table.

[14] Ratio of income to poverty level in the past 12 months by nativity of children under 18 years in families and subfamilies by living arrangement and nativity of parents. https://factfinder.census.gov/faces/tableservices/jsf/pages/productview.X html?pid=ACS_15_1YR_B05010\&prodType=table.

[15] Poverty status in the past 12 months of families by family type by social security income by supplementary security income (SSI) and cash public assistance. income. https://factfinder.census.gov/faces/tableservices/jsf/pages/productview.X html?pid=ACS_15_1YR_B17015\&prodType=table.

[16] Ration of Income to poverty level in the past 12 months universe: Population for whom poverty status is determined 2015 American $\begin{array}{llll}\text { Community } & \text { Survey } & 1-Y e a r & \text { Estimates }\end{array}$ https://factfinder.census.gov/faces/tableservices/jsf/pages/productview.X html?pid=ACS_15_1YR_B17002\&prodType=table. 